to provide a framework within which departments and research councils can work in partnership while allowing for the occasional major difference of view to be discussed and determined at every 1 evel.

Yours faithfully,

\section{JOHN LYONS}

\section{Institution of Professional}

Civil Servants,

Northumberland Street,

London WC2N $5 B S$

\section{Publication Speed}

Sir,-I am pleased to see that Mr St Aubyn has, in responding to my letter, taken the opportunity of giving us some good advice on how to get our papers published (Nature, 235, 447; 1972). I am unsure about the sin that $I$ and a number of other contributors have committed. I had always believed that while it was quite true that I could not eat my cake and have it I could certainly have it and eat it. I agree, I think, with the substance of every point that he makes in his letter, but disagree considerably about their importance.
Journals must, of course, have stringent refereeing procedures, but there is no need for this to take longer than, say, three months. Drs Rose-Innes and Lipman (Physics Bulletin; September 1971, 527-8) tell us that a good PhD thesis (longer than $\mathrm{Mr}$ St Aubyn's already excessive 8,000 words) takes about the pre-electrification time from Manchester to London to read and assess. All working scientists read research reports and critically evaluate them for their own purposes in very short periods of time. Three months seems a maximum for these decisions.

I would agree that there are likely to be some cases where the subject matter of submissions is so technical that a generalist editor cannot know whether it suits his journal or not. This surely cannot be the case on other than an insignificant number of occasions; surely it is this matter of relevance which is above all the responsibility of the editor.

Finally, I'm sure that the majority of readers of my original letter will know that I never suggested that authors should adopt the practice of multiple publication. I merely stated that in the case in which many journals are clearly so inefficient the editors should not be too surprised if this device was used as a tactic to ensure speedy and full publication.

Yours faithfully,

I. D. GRIFFIths

The Electricity Council

Research Centre,

Capenhurst,

Chester CH1 6ES

\section{Knuckle Walking}

SIR,-Russell Tuttle and Benjamin B. Beck state (Nature, 236, 34; 1972): "Man, too, often rests his flexed fingers in facultative knuckle-walking postures, as may be witnessed in certain public speakers and football linesmen". But surely the distinctive hand flexure of linesmen is due to the fact that they must hold a stop-watch in their non-flag-waving hand, the face of which must be easily visible? Is it different in Chicago? Does this affect the evolutionary inferences?

$$
\text { Yours faithfully, }
$$

$$
\text { E. N. Tiratsoo }
$$

9, Cambridge Road,

Beaconsfield, Bucks

\title{
Obituary
}

\section{Dr John Dennis Carthy}

JoHN CARTHY, who died on March 13, was a man of many talents and much of the success and enjoyment which he achieved was brought about by the ease with which he combined them. His main scientific interests were in animal behaviour, but his knowledge and lively enthusiasm soon led him into activities where his ability to understand and communicate this work became appreciated by many. Those who met him found a warm and friendly personality which quickly made him a most approachable and rewarding colleague.

John Carthy was born in Plymouth in 1923 and educated at Bedford School and Christ's College, Cambridge, where he took the Natural Sciences Tripos in 1947. For the next three years he was engaged in postgraduate work under Professor W. H. Thorpe on problems of the orientation of ants and their use of odour trails. $\mathrm{He}$ was awarded the degree of $\mathrm{PhD}$ in 1950 and left Cambridge to join the academic staff of Queen Mary College, University of London, where he remained for the next seventeen years. During this period he extended his behavioural interests to include research on sensory physiology and cell ultrastructure. The research published on these problems included investigations on the electrophysiology of the eye of the "whiligig" beetle, the fine structure of the sensory pegs of scorpion pectines and field observations on the behaviour of a variety of arthropods. A number of successful postgraduates were trained under him at this time on topics as diverse as the significance of olfaction and vibration in termites to the social behaviour of the Red Avadaat. He was also involved in the establishment of a successful biological electron microscopy unit at Queen Mary College.

In 1952 John Carthy went on an expedition to the Azores and wrote a number of papers on the insect fauna of the isles of Pico and Fayal. An excellent entomologist and field worker, he blended these interests with his behavioural work so that he was eminently suited to be appointed in 1967 as the first Scientific Director of the Field Studies Council. In this capacity he travelled around the country a great deal, and soon became a familiar figure at the field stations, where he encouraged a whole range of research interests among the staff. He was particularly proud of the Oil Pollution Research Unit which was set up at Orielton and shared the concern for the environ- ment expressed in the joint publication on the Biological Effects of Oil Pollution on Littoral Communities.

To many John Carthy will be remembered as a scientist who carried his subject to a wide audience by his radio and television appearances. Others will have read his many books, of which Animal Navigation, An Introduction to the Behaviour of Invertebrates, The Behaviour of Arthropods, Animal Behaviour and The Study of Behaviour are perhaps the best known for the clear and enjoyable style which appeared in these and later publications and which attracted a whole generation of biologists. The extent of the impact which these books had can be judged from the fact that they were translated into Spanish, Italian, Dutch, Swedish and German. These popular achievements were, however, based on the solid foundation of an understanding of scientific research and its implications and it was for the same reason that he was in heavy demand by the scientific community. He served as Secretary to the Society for Experimental Biology and the Association for the Study of Animal Behaviour and was a section secretary for the British Association for the Advancement of Science, of which he was also a Council member. He was 